Article

\title{
Antibiotics, Acid and Heat Tolerance of Honey adapted Escherichia coli, Salmonella Typhi and Klebsiella pneumoniae
}

\author{
Rabia Ayub ${ }^{1}$, Muhammad Umer ${ }^{1}$, Abid Aslam Maan ${ }^{2}$, Bilal Rasool ${ }^{3}$, \\ Muhammad Kashif Iqbal Khan ${ }^{2, *(D)}$, Tahira Younis ${ }^{3}$, Shabbar Abbas ${ }^{1}$ (D), Muhammad Sajjad ${ }^{1}$ (D), \\ Imdad Kaleem ${ }^{1}$, Muhammad Imran ${ }^{4}$, Azmat Ullah ${ }^{5}$, Muhammad Sohail Afzal ${ }^{6} \mathbb{D}$, \\ Zaheer Hussain Shah ${ }^{7}$, Sheraz Ahmed ${ }^{8}$, Farhan Aslam ${ }^{9}$, Neelam Chaudhary ${ }^{10}$ and \\ Muhammad Inam Afzal ${ }^{1, *(1)}$ \\ 1 Department of Biosciences, COMSATS University Islamabad, Park road, Tarlai kalan, Islamabad 45550, \\ Pakistan; rabiaayub54@gmail.com (R.A.); umer.imperial@gmail.com (M.U.); \\ shabbar.abbas@comsats.edu.pk (S.A.); msajjadpbg@gmail.com (M.S.); kaleem.imdad@comsats.edu.pk (K.I.) \\ 2 Department of Food Engineering, University of Agriculture, Faisalabad 38000, Pakistan; \\ abid.maan@uaf.edu.pk \\ 3 Department of Zoology, Faculty of Life Sciences, Government College University, Faisalabad 38000, Pakistan; \\ bilalrasool@gcuf.edu.pk (B.R.); tahirayounis@gmail.com (T.Y.) \\ 4 University Institute of Diet and Nutritional Sciences, Faculty of Allied Health Sciences, The University of \\ Lahore, Lahore 54000, Pakistan; mic_1661@yahoo.com \\ 5 Department of Food Science and Human Nutrition, University of Veterinary and Animal Sciences, \\ Out Fall Road, Civil Lines, Lahore 54000, Pakistan; azmat.khan@uvas.edu.pk \\ 6 Department of Life Sciences, University of Management and Technology, Lahore 54000, Pakistan; \\ sohail.ncvi@gmail.com \\ 7 Department of Physics, University of Management and Technology, Lahore 54000, Pakistan; \\ zaheer.hussain@umt.edu.pk \\ 8 Department of Food Sciences, Faculty of Bioscience, Cholistan University of Veterinary and Animal Sciences, \\ Bahawalpur 63100, Pakistan; drsherazahmed@gmail.com \\ 9 Department of Food Science and Human Nutrition, University of Veterinary and Animal Sciences, \\ Lahore 54000, Pakistan; farhanaslam111@yahoo.com \\ 10 Department of Continuing Education, University of Agriculture, Faisalabad 38000, Pakistan; \\ neelam.imperial@gmail.com \\ * Correspondence: kashif.khan@uaf.edu.pk (M.K.I.K.); dr-miafzal@hotmail.com (M.I.A.)
}

Received: 2 October 2019; Accepted: 3 March 2020; Published: 9 March 2020

\begin{abstract}
The medicinal importance of honey has been known for many decades due to its antimicrobial properties against life-threatening bacteria. However, previous studies revealed that microorganisms are able to develop adaptations after continuous exposure to antimicrobial compounds. The present study was conducted to explore the impact of subinhibitory concentrations of branded honey (Marhaba) and unbranded honey (extracted from Ziziphus mauritiana plant) locally available in Pakistan on Escherichia coli ATCC 10536, Salmonella Typhi and Klebsiella pneumoniae by investigating the development of self- or cross-resistance to antibiotics (gentamicin, kanamycin and imipenem). Minimum inhibitory concentration (MIC) and minimum bactericidal concentration (MBC) of autoclaved honeys were determined. The bacterial cells of E. coli ATCC 10536, S. Typhi and K. pneumoniae were subjected to honey adaptation by exposing to $\frac{1}{4} \times \mathrm{MIC}$ (4 passages) and $\frac{1}{2}$ $\times$ MIC (4 passages) of both honeys. Moreover, tolerance to low $\mathrm{pH}$ and high temperature was also studied in adapted and unadapted cells. The decreasing trend in growth pattern $\left(\mathrm{OD}_{600 \mathrm{~nm}}\right)$ of $E$. coli ATCC 10536, S. Typhi and K. pneumoniae was observed with increases in the concentration of honeys $(6.25-50 \% v / v)$ respectively. Our results showed that continuous exposure of both honeys did not lead to the development of any self- or cross-resistance in tested bacteria. However, percent survival to low
\end{abstract}


$\mathrm{pH}$ was found to be significantly higher in adapted cells as compared to unadapted cells. The results indicate that both branded honey (Marhaba) and unbranded honey (extracted from Ziziphus mauritiana plant) were effective in controlling the growth of tested pathogenic bacteria. However, the emergence of tolerance to adverse conditions ( $\mathrm{pH} 2.5$, temperature $60^{\circ} \mathrm{C}$ ) deserves further investigation before proposing honey as a better antibacterial agent in food fabrication/processing, where low $\mathrm{pH}$ and high temperatures are usually implemented.

Keywords: honey; Escherichia coli; Salmonella Typhi; Klebsiella pneumoniae; microbial adaptation; stress resistance

\section{Introduction}

The development of antibiotic resistance in pathogenic microorganisms is a major threat to human health which could accelerate the mortality rate. In the present era, scientists are trying to overcome this concern through the incorporation of natural compounds in foods as a supplement or medicines [1]. Nowadays, the research has rapidly focused on honey due to its natural origin, with antimicrobial, antifungal and anti-inflammatory properties [2]. Honey is a natural food that contains numerous compounds playing an important role in the development of advanced medicines [3].

Honey is a saccharine exudation produced by plants and gathered by different species of honeybees comprising $80-85 \%$ carbohydrates, $15-17 \%$ water, $0.1-0.4 \%$ protein, and $0.2 \%$ ash, minute quantity of amino acids, phenolic content, enzymes and vitamins [4,5]. In the US, 300 different varieties of honey are reported on the basis of different floral origin [6]. It is a great source of flavonoids, phenolic acids and antioxidants (catalase, glucose oxidase, carotenoid derivatives, organic acids, ascorbic acid, amino acids and proteins) [6]. The worldwide annual production of honey is approximately 1.2 million tons [7]. It has been used since ancient times for its nutritional as well as curative properties [8]. The use of honey as medicine started six thousand years ago [9]. Ancient Greek athletes used water and honey mixture to overcome fatigue [2]. The ancient Egyptians, Chinese, Romanians and Assyrians used honey for wound healing and treatment of gut infections [2]. The wound healing property of honey seemed to be directly linked to its antimicrobial activity $[10,11]$. Various types of honey were found to possess antimicrobial activity against antibiotic resistant pathogenic microorganisms [12].

Previous studies highlighted the antimicrobial activity of different types of honey in terms of their botanical sources against pathogenic microorganisms, for instance, Staphylococcus aureus, E. coli, S. Typhi, Bacillus cereus, B. subtilis, Streptococcus pyogenes and Shigella spp. [4,13]. The honey extracted from Apis indica was found to be very effective against E. coli, S. enterica serovar Typhi and P. aeruginosa isolated from urinary tract infections, skin lesions and enteric fever [10]. A high synergistic effect of honey was observed when it was added to antibiotics against gram-negative bacteria and coagulase-positive staphylococci [14]. The strong effect of honey was observed in the detachment of biofilm by using magnesium oxide present in honey [15]. A study conducted on Manuka honey showed strong abolition of Proteus mirabilis and Enterobacter cloacae biofilms [15].

The aim of the present study was to explore the impact of subinhibitory concentrations of branded honey (Marhaba) and unbranded honey (extracted from Ziziphus mauritiana plant) locally available in Pakistan on E. coli ATCC 10536, S. Typhi and K. pneumoniae by investigating the development of selfor cross-resistance to antibiotics (gentamicin, kanamycin and imipenem). Moreover, tolerance to low $\mathrm{pH}$ and high temperature was also studied in adapted and unadapted cells. 


\section{Materials and Methods}

\subsection{Bacterial Strains and Reagents}

Two bacterial pathogens including S. Typhi and K. pneumoniae, along with one reference strain, E. coli ATCC 10536 were used in this study. The strains and isolates were provided by Pakistan Institute of Medical Sciences (PIMS) Islamabad, Pakistan and Microbiology and Public Health Laboratory, COMSATS University Islamabad, Pakistan. Cultures were revived and grown in tryptic soy broth supplemented with yeast extract (TSB-YE) and incubated at optimum growth temperatures at $37^{\circ} \mathrm{C}$. Three antibiotics (kanamycin, imipenem and gentamicin) were purchased from Thermo Fisher Scientific UK, Merck USA and Barrett Hodgson Pakistan.

\subsection{Honey Collection and Storage}

Branded honey (Marhaba) was purchased from a supermarket of Islamabad, Pakistan and unbranded honey (extracted from Ziziphus mauritiana plant) was obtained from National Agriculture Research center (NARC), Islamabad, Pakistan. The chemical composition of branded honey (Marhaba) was previously reported [16]. The honey samples were kept in tightly sealed bottles in the dark at room temperature and autoclaved at $121^{\circ} \mathrm{C}$ for $15 \mathrm{~min}$ before antimicrobial assays.

\subsection{Determination of Minimum Inhibitory Concentrations (MICs) of Honeys and Antibiotics against Bacterial Isolates}

Antimicrobial activity of branded honey (Marhaba), unbranded honey (extracted from Ziziphus mauritiana plant) and antibiotics (kanamycin, imipenem and gentamicin) against E. coli ATCC 10536, S. Typhi and K. pneumoniae was explored by using agar dilution and the spot inoculation method according to Clinical and Laboratory Standards Institute (CLSI, 2012) [17], with some modifications. Different concentrations of each honey (1.56-50\% $v / v)$ and antibiotics including kanamycin $(0.5-8 \mu \mathrm{g} / \mathrm{mL})$, imipenem $(0.0075-0.24 \mu \mathrm{g} / \mathrm{mL})$ and gentamicin $(0.5-2 \mu \mathrm{g} / \mathrm{mL})$ were selected as reported previously $[10,18]$. The plates were then divided into different sectors for spot inoculation of strains. Prior to each experiment, all tested microorganisms were sub-cultured in TSB-YE and incubated at $37^{\circ} \mathrm{C}$ for $24 \mathrm{~h}$. Bacterial cell suspensions were adjusted to $0.5 \mathrm{McF}$ arland equivalents in a sodium chloride solution $(0.85 \% w / v)$ and subsequently diluted to achieve a cell suspension with approximately $1 \times 10^{6}$ colony forming units per $\mathrm{mL}(\mathrm{CFU} / \mathrm{mL}) .1-2 \mu \mathrm{L}$ of each bacterial culture was inoculated on each spot on plates and incubated at $37^{\circ} \mathrm{C}$ for $18-24 \mathrm{~h}$. The TSA-YE plates without honeys or antibiotics were also inoculated as a control to check the growth of bacterial strains. Samples were subjected to bacterial numeration for the assessment of viable cells for bactericidal concentration. The minimum inhibitory concentrations (MIC) and minimum bactericidal concentration (MBC) values were noted after $24 \mathrm{~h}$ [10]. Three biological replicates were used.

\subsection{Determination of the Effect of Branded and Unbranded Honey on Bacterial Growth}

Bacterial cultures were prepared as described above with approximately $10^{6} \mathrm{CFU} / \mathrm{mL}$. Growth response of E. coli ATCC 10536, S. Typhi and K. pneumoniae in TSB-YE was evaluated by treating bacterial cultures with different concentrations of branded and unbranded honeys $(0,6.25,12.5,25$ and $50 \% \mathrm{v} / \mathrm{v}$ ) during $48 \mathrm{~h}$ of incubation at $37^{\circ} \mathrm{C}$. Three biological replicates were used.

\subsection{Adaptation to Branded and Unbranded Honey}

The adaptation assays were performed by using branded and unbranded honey against E. coli ATCC 10536, S. Typhi and K. pneumoniae as described previously [19] with some modifications. The bacterial cells $\left(1 \times 10^{8} \mathrm{CFU} / \mathrm{mL}\right)$ were exposed to $\frac{1}{4}, \frac{1}{2}, 1$ and $2 \times$ MIC values of branded and unbranded honey respectively. $10 \mu \mathrm{L}$ of each cell suspension $\left(1 \times 10^{8} \mathrm{CFU} / \mathrm{mL}\right)$ was inoculated in $6 \mathrm{~mL}$ TSB-YE and incubated for $24 \mathrm{~h}$ at $37^{\circ} \mathrm{C}$. The bacterial growth was monitored during each passage by measuring optical density $\left(\mathrm{OD}_{600 \mathrm{~nm}}\right)$ at 0 and $24 \mathrm{~h}$ at $37^{\circ} \mathrm{C}$ of incubation using a spectrophotometer. 
The $24 \mathrm{~h}$ incubated samples $(100 \mu \mathrm{L})$ were centrifuged $\left(8000 \times g, 5\right.$ min at $\left.4{ }^{\circ} \mathrm{C}\right)$ and supernatants were discarded. After the first passage, $1 \mathrm{~mL}$ of fresh TSB-YE (previously adjusted to $\frac{1}{4} \times$ MIC) was added in tubes containing cell pellets. The step was repeated 4 times (4 passages) for $\frac{1}{4} \times$ MIC concentration. After the fourth passage, $1 \mathrm{~mL}$ of fresh TSB-YE (previously adjusted to $\frac{1}{2} \times$ MIC) was added in tubes containing cell pellets. The step was repeated 4 times (4 passages). After the eighth passage, $1 \mathrm{~mL}$ of fresh TSB-YE (previously adjusted to $1 \times$ MIC) was added in tubes containing cell pellets. The step was repeated 4 times (4 passages). After the twelfth passage, $1 \mathrm{~mL}$ of fresh TSB-YE (previously adjusted to $2 \times$ MIC) was added in tubes containing cell pellets. Honey concentrations were subsequently increased until there was no cell growth. The assays were followed by a growth control with bacterial cultures being inoculated in TSB-YE without the addition of honeys. Three biological replicates were used.

\subsection{Determination of Adaptive and Cross-Resistance in Bacterial Isolates}

The adaptive and cross-resistance was evaluated in E. coli ATCC 10536, S. Typhi and K. pneumoniae after the 4 th passage of cells against $\frac{1}{4} \times$ MIC and the 4th passage with $\frac{1}{2} \times$ MIC respectively. Adapted cells were evaluated for MIC and MBC values of honeys using agar dilution and spot inoculation method as described above [20].

\subsection{Determination of Tolerance to Acid and Heat}

Tolerance to acid ( $\mathrm{pH} 2.5)$ and heat $\left(60^{\circ} \mathrm{C}\right)$ was performed as described previously [21] with some modifications. Acid tolerance assays were performed by taking $25 \mu \mathrm{L}$ of adapted and unadapted cell suspensions $\left(10^{6} \mathrm{CFU} / \mathrm{mL}\right)$ and added to tubes containing $4975 \mu \mathrm{L}$ of TSB-YE acidified to $\mathrm{pH} 2.5 \mathrm{using}$ hydrochloric acid and incubated at $37^{\circ} \mathrm{C}$. Heat tolerance assays were conducted by taking $25 \mu \mathrm{L}$ of adapted and unadapted cell suspensions $\left(10^{6} \mathrm{CFU} / \mathrm{mL}\right)$ and added to tubes containing $4975 \mu \mathrm{L}$ of TSB-YE incubated at $60{ }^{\circ} \mathrm{C}$ in a thermostatic water bath. Bacterial viable counting was performed via the pour plate method by taking samples during 0-120 min. Three independent experiments were conducted.

\subsection{Statistical Analysis}

Mean and standard deviations were determined for each treatment intervals. Data were analyzed using one-way ANOVA, with association between treatments. The analysis was assessed for significance at $p<0.05$ [22].

\section{Results and Discussion}

\subsection{Minimum Inhibitory Concentrations and Effects of Honeys on Bacterial Growth}

The MIC values of branded honey were found to be $12.5 \% v / v$ against $S$. Typhi and $25 \% v / v$ against E. coli ATCC 10536 and K. pneumoniae. The MBC values of branded honey were observed as $25 \%$ $v / v$ against $S$. Typhi and 50\% $v / v$ against E. coli ATCC 10536 and K. pneumoniae. The MIC value of unbranded honey was found to be $25 \%$ v/v against S. Typhi, E. coli ATCC 10536 and K. pneumoniae. The MBC value of unbranded honey was noted as 50\% v/v against $S$. Typhi, E. coli ATCC 10536 and K. pneumoniae.

Growth pattern of E. coli ATCC 10536, S. Typhi and K. pneumoniae treated with different concentrations of branded and unbranded honey is shown in Figure 1. All bacterial cultures grew well in the absence (control) and presence of $3.125 \%(v / v)$ of honeys. Branded and unbranded honey started to show growth inhibition as compared to control at 6.25\% (v/v) for E. coli ATCC 10536 and K. pneumoniae, $12.5 \%(v / v)$ for $S$. Typhi. Minimum bactericidal concentrations of honeys were achieved at 25\% (v/v) for E. coli ATCC 10536, S. Typhi and K. pneumoniae. A similar decreasing trend in growth was observed in S. aureus with increases in concentration of honeys (Manuka, Nigella and Sidr) ranging from 10 to $50 \%(v / v)$ in nutrient broth [18]. 

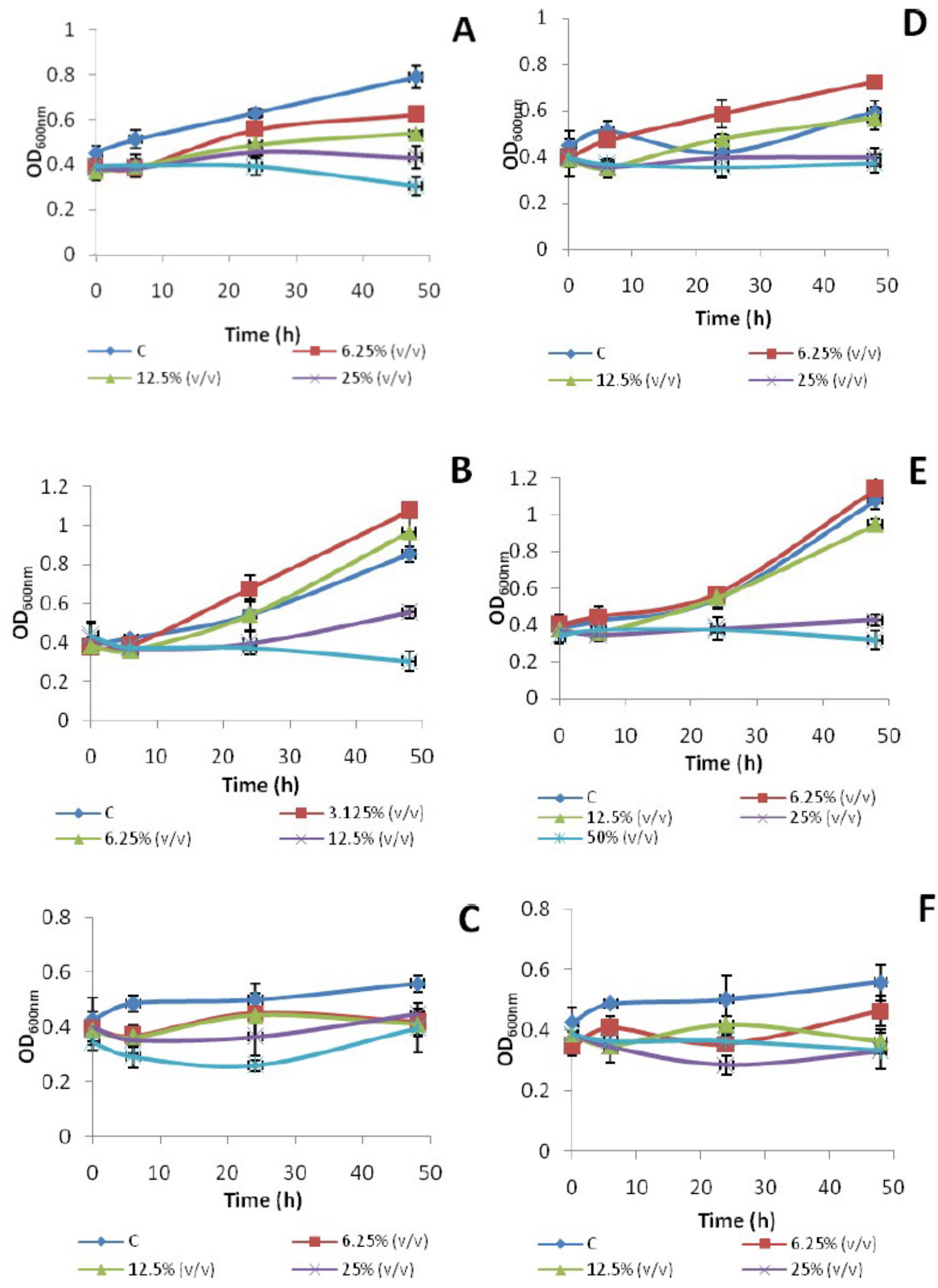

Figure 1. Effect of different concentrations of branded honey (Marhaba) (A-C) and unbranded honey (extracted from Ziziphus mauritiana plant) (D-F) on bacterial growth (OD $600 \mathrm{~nm})$ of E. coli ATCC 10536 (A,D), S. Typhi (B,E) and K. pneumoniae (C,F).

Antimicrobial activity of honeys related to coniferous, thyme and polyfloral origin against certain pathogenic microorganisms was highlighted by Olaitan and Voidarou [4,13]. The MIC of Ulmo honey 
was found to be $12.5 \%(v / v)$ for P. aeruginosa and E. coli $[4,13]$. The MICs of Manuka honey and Tualang honey ranged from $8.75 \%-25 \%(v / v)$ for many gram positive and gram negative pathogenic bacteria. The MICs of Nilgiri honey for E. coli, S. aureus and P. aeruginosa were noted as $40 \%, 35 \%$ and $25 \%(v / v)$, respectively [11].

\subsection{Adaptation to Subinhibitory Concentrations of Branded and Unbranded Honey}

The variation in growth of E. coli ATCC 10536, S. Typhi and K. pneumoniae treated with $\frac{1}{4} \times$ MIC, $\frac{1}{2} \times$ MIC, $1 \times$ MIC and 2x MIC is shown in Table 1. The exposure to subinhibitory concentrations of branded and unbranded honey induced low adaptation in E. coli ATCC 10536, S. Typhi and K. pneumoniae. A prominent decreased growth was observed from the fourth passage at $\frac{1}{4} \times$ MIC to the first passage at $\frac{1}{2} \times$ MIC of branded honey in E. coli ATCC $10536(2.33 \pm 0.03$ to $1.69 \pm 0.10)$ and K. pneumoniae $(2.73 \pm$ 0.21 to $1.57 \pm 0.17)$. However, from the second to the third passage at $\frac{1}{2} \times \mathrm{MIC}$, a significant increase in growth was observed in K. pneumoniae $(p<0.05)$ which might be linked to cellular changes, indicative of an adaptation to branded honey. No significant difference in growth was observed from the second to the fourth passage at $\frac{1}{2} \times$ MIC of unbranded honey in E. coli ATCC 10536 and S. Typhi. An accentuated decrease in growth was observed from the fourth passage at $\frac{1}{4} \times$ MIC to the first passage at $\frac{1}{2} \times$ MIC of unbranded honey in E. coli ATCC 10536 (2.11 \pm 0.06 to $1.57 \pm 0.15)$ and K. pneumoniae $(2.63 \pm 0.06$ to $1.36 \pm 0.25)$. Nevertheless, a remarkable increase in growth was recorded in $K$. pneumoniae $(p<0.05)$ at $\frac{1}{2} \times$ MIC from the second to the third passage, which suggests that this type of cellular variation also shows adaptation to unbranded honey. The exposure to subinhibitory concentrations of honeys was found to induce low adaptation of E. coli ATCC 10536 and K. pneumoniae to the compound as observed previously by $S$. aureus against subinhibitory concentrations of resveratrol [23]. A decreasing growth trend was observed from the fourth passage at $\frac{1}{4} \times \mathrm{MIC}$ until the fourth passage at $1 \times$ MIC for all bacteria possibly because the cells were not in a state to cope with increasing inhibitory concentrations of honeys. No growth was observed when cells were exposed to $2 \times \mathrm{MIC}$ values of honeys. The continuous exposure of bacteria to $\frac{1}{4}$ and $\frac{1}{2} \times \mathrm{MIC}$ of honeys helped in the selection of bacterial population that became adapted or tolerant to antimicrobial compounds, possibly due to changes in over-expression and efflux pumps [24].

\subsection{Impact of Honey Adaptation on the Development of Self or Cross-resistance}

The MICs of branded honey remained the same in adapted and unadapted cells of E. coli ATCC 10536 (25\% v/v), S. Typhi (12.5\% v/v) and K. pneumoniae (25\% v/v) (Table 2). Similarly, MICs of unbranded honey did not change for adapted and unadapted cells of E. coli ATCC $10536(25 \% v / v)$, S. Typhi $(25 \% v / v)$ and K. pneumoniae (25\% $v / v)$. MIC of gentamycin $(2 \mu \mathrm{g} / \mathrm{mL})$, kanamycin $(8 \mu \mathrm{g} / \mathrm{mL})$ and imipenem $(0.12 \mu \mathrm{g} / \mathrm{mL})$ remained the same in adapted and unadapted cells of tested bacteria. The same pattern was observed for adapted cells of $S$. aureus and L. monocytogenes against resveratrol, ampicillin, erythromycin, vancomycin and benzalkonium chloride [23]. On the contrary, Cooper and colleagues [25] observed a temporary increase in MIC of Manuka honey against adapted cells of E. coli, P. aeruginosa and S. epidermidis [25]. Apolónio and colleagues [19] observed no resistance development in S. aureus and L. monocytogenes when continuously exposed to subinhibitory concentrations of eugenol and citral. 
Table 1. Variation in growth of E. coli ATCC 10536, S. Typhi and K. pneumoniae at subinhibitory and inhibitory concentrations of branded and unbranded honey.

\begin{tabular}{|c|c|c|c|c|c|c|c|c|c|c|c|c|}
\hline \multicolumn{2}{|c|}{$\begin{array}{c}\text { Preservative } \\
\text { Concentration/Passage }\end{array}$} & \multicolumn{2}{|c|}{ E. coli ATCC 10536} & \multirow[b]{2}{*}{$2 \times \mathrm{MIC}$} & \multicolumn{4}{|c|}{ S. Typhi } & \multicolumn{4}{|c|}{ K. pneumoniae } \\
\hline & $\frac{1}{4} \times$ MIC & $\frac{1}{2} \times$ MIC & $1 \times$ MIC & & $\frac{1}{4} \times$ MIC & $\frac{1}{2} \times$ MIC & $1 \times$ MIC & $2 \times \mathrm{MIC}$ & $\frac{1}{4} \times$ MIC & $\frac{1}{2} \times$ MIC & $1 \times$ MIC & $2 \times$ MIC \\
\hline \multicolumn{13}{|l|}{ Control } \\
\hline 1st & $2.23 \pm 0.15^{\mathrm{a}}$ & $1.81 \pm 0.51^{\mathrm{a}}$ & $1.21 \pm 0.21^{\mathrm{a}}$ & $1.92 \pm 0.65$ & $2.15 \pm 0.02^{\mathrm{a}}$ & $1.85 \pm 0.25^{\mathrm{a}}$ & $1.15 \pm 0.16^{\mathrm{a}}$ & $1.41 \pm 0.12$ & $2.32 \pm 0.26^{\mathrm{a}}$ & $1.81 \pm 0.02^{\mathrm{a}}$ & $1.29 \pm 0.28^{\mathrm{a}}$ & $2.22 \pm 0.45$ \\
\hline 2nd & $2.44 \pm 0.23^{\mathrm{a}}$ & $1.96 \pm 0.68^{b}$ & $1.75 \pm 0.65^{b}$ & & $1.81 \pm 0.14^{\mathrm{b}}$ & $1.92 \pm 0.14^{\mathrm{a}}$ & $1.52 \pm 0.03^{b}$ & & $1.85 \pm 0.14^{\mathrm{b}}$ & $1.88 \pm 0.08^{\mathrm{a}}$ & $1.81 \pm 0.15^{b}$ & \\
\hline 3 rd & $2.15 \pm 0.35^{\mathrm{a}}$ & $1.35 \pm 0.85^{c}$ & $1.69 \pm 0.45^{c}$ & & $2.36 \pm 0.05$ a c & $1.30 \pm 0.04 \mathrm{bc}$ & $1.53 \pm 0.22 \mathrm{bc}$ & & $2.71 \pm 0.08^{c}$ & $1.24 \pm 0.15^{b}$ & $1.32 \pm 0.06^{\mathrm{ac}}$ & \\
\hline 4th & $2.44 \pm 0.08^{\mathrm{a}}$ & $1.52 \pm 0.64^{\mathrm{d}}$ & $1.86 \pm 0.85^{\mathrm{d}}$ & & $2.52 \pm 0.21^{\mathrm{c}}$ & $1.41 \pm 0.07^{\mathrm{c}}$ & $1.48 \pm 0.13^{\mathrm{bcd}}$ & & $2.10 \pm 0.15^{\mathrm{ab}}$ & $1.53 \pm 0.18^{\mathrm{c}}$ & $1.61 \pm 0.01^{\mathrm{bc}}$ & \\
\hline \multicolumn{13}{|l|}{ Branded honey } \\
\hline 1st & $2.58 \pm 0.05^{\mathrm{a}}$ & $1.69 \pm 0.10^{\mathrm{a}}$ & $1.21 \pm 0.04^{\mathrm{a}}$ & NG * & $1.43 \pm 0.31^{\mathrm{a}}$ & $1.53 \pm 0.10^{\mathrm{a}}$ & $1.10 \pm 0.21^{\mathrm{a}}$ & NG* & $1.84 \pm 0.04 \mathrm{a}$ & $1.57 \pm 0.17^{\mathrm{a}}$ & $1.08 \pm 0.12^{\mathrm{a}}$ & $\mathrm{NG}^{*}$ \\
\hline 2nd & $1.82 \pm 0.09^{\mathrm{a}}$ & $1.54 \pm 0.01^{\mathrm{a}}$ & $1.09 \pm 0.08^{b}$ & & $1.39 \pm 0.05^{\mathrm{a}}$ & $1.03 \pm 0.24^{b}$ & $1.65 \pm 0.07^{\mathrm{b}}$ & & $1.89 \pm 0.09$ a & $1.24 \pm 0.11^{b}$ & $1.04 \pm 0.05^{\mathrm{a}}$ & \\
\hline 3 rd & $1.57 \pm 0.01^{\mathrm{a}}$ & $1.70 \pm 0.05^{\mathrm{a}}$ & $1.27 \pm 0.03^{a}$ & & $1.49 \pm 0.08^{\mathrm{a}}$ & $1.18 \pm 0.05^{b c}$ & $1.41 \pm 0.06^{\mathrm{bc}}$ & & $0.86 \pm 0.15^{b}$ & $1.74 \pm 0.03^{\mathrm{a}}$ & $1.24 \pm 0.30^{\mathrm{a}}$ & \\
\hline 4th & $2.33 \pm 0.03^{\mathrm{a}}$ & $1.26 \pm 0.12^{b}$ & $1.11 \pm 0.15^{\mathrm{a}}$ & & $1.53 \pm 0.04 \mathrm{a}$ & $1.09 \pm 0.09 \mathrm{bcd}$ & $1.02 \pm 0.01^{\mathrm{a}}$ & & $2.73 \pm 0.21^{\mathrm{c}}$ & $1.25 \pm 0.14 \mathrm{bc}$ & $1.20 \pm 0.21^{\mathrm{a}}$ & \\
\hline \multirow{2}{*}{\multicolumn{13}{|c|}{$\begin{array}{l}\text { Unbranded } \\
\text { honey }\end{array}$}} \\
\hline & & & & & & & & & & & & \\
\hline 1st & $2.61 \pm 0.02^{\mathrm{a}}$ & $1.57 \pm 0.15^{\mathrm{a}}$ & $1.14 \pm 0.05^{\mathrm{a}}$ & $\mathrm{NG}^{*}$ & $1.32 \pm 0.05^{\mathrm{a}}$ & $1.37 \pm 0.14^{\mathrm{a}}$ & $1.00 \pm 0.12^{\mathrm{a}}$ & $\mathrm{NG}^{*}$ & $2.15 \pm 0.07^{\mathrm{a}}$ & $1.36 \pm 0.25^{\mathrm{a}}$ & $0.96 \pm 0.02^{\mathrm{a}}$ & $\mathrm{NG}^{*}$ \\
\hline 2nd & $1.65 \pm 0.08^{\mathrm{a}}$ & $1.22 \pm 0.04 \mathrm{a}$ & $1.25 \pm 0.14^{\mathrm{a}}$ & & $1.63 \pm 0.15^{b}$ & $1.29 \pm 0.16^{\mathrm{a}}$ & $1.12 \pm 0.18^{\mathrm{a}}$ & & $1.94 \pm 0.15^{b}$ & $1.33 \pm 0.14^{\mathrm{a}}$ & $1.08 \pm 0.03 \mathrm{ac}$ & \\
\hline 3 rd & $1.31 \pm 0.01^{\mathrm{b}}$ & $1.55 \pm 0.19^{\mathrm{a}}$ & $1.12 \pm 0.03 \mathrm{a}$ & & $1.80 \pm 0.17 \mathrm{bc}$ & $1.43 \pm 0.05^{\mathrm{a}}$ & $1.30 \pm 0.09 \mathrm{a}$ & & $1.64 \pm 0.02^{c}$ & $1.44 \pm 0.06^{\mathrm{a}}$ & $1.27 \pm 0.10^{b}$ & \\
\hline 4th & $2.11 \pm 0.06^{c}$ & $1.53 \pm 0.02^{\mathrm{a}}$ & $1.29 \pm 0.01^{\mathrm{a}}$ & & $2.18 \pm 0.06^{\mathrm{d}}$ & $1.61 \pm 0.08^{\mathrm{a}}$ & $1.12 \pm 0.04^{\mathrm{a}}$ & & $2.63 \pm 0.06^{\mathrm{d}}$ & $1.29 \pm 0.08^{\mathrm{a}}$ & $1.17 \pm 0.08$ bc & \\
\hline
\end{tabular}

* Growth variation after each passage in shown as the ration between $\mathrm{OD}_{600 \mathrm{~nm}}$ at $\mathrm{T}_{24}$ and $\mathrm{OD}_{600 \mathrm{~nm}}$ at $\mathrm{T}_{0}\left(\mathrm{ODT}_{24} / \mathrm{ODT}_{0}\right)$. NG: no growth. Data are representative of three replicates $\pm \mathrm{SD}_{\text {. }}$ (Branded honey against E. coli and K. pneumoniae: $\left.\frac{1}{4} \times \mathrm{MIC}=6.25 \% v / v ; \frac{1}{2} \times \mathrm{MIC}=12.5 \% v / v ; 1 \times \mathrm{MIC}=25 \% v / v ; 2 \times \mathrm{MIC}=50 \% v / v\right)$. (Branded honey against $S$. Typhi: $\frac{1}{4} \times \mathrm{MIC}=3.125 \% v / v$; $\left.\frac{1}{2} \times \mathrm{MIC}=6.25 \% v / v ; 1 \times \mathrm{MIC}=12.5 \% v / v ; 2 \times \mathrm{MIC}=25 \% v / v\right)$. (Unbranded honey against $E$. coli, S. Typhi and K. pneumoniae: $\frac{1}{4} \times \mathrm{MIC}=6.25 \% v / v ; \frac{1}{2} \times \mathrm{MIC}=12.5 \% v / v ; 1 \times \mathrm{MIC}=25 \% v / v ;$ $2 \times \mathrm{MIC}=50 \% v / v)$. Data in columns with different superscript letters are significantly different $(p<0.05)$.

Table 2. Minimum inhibitory concentration (MIC) (\% v/v) of branded and unbranded honey against E. coli ATCC 10536, S. Typhi and K. pneumoniae after fourth passage of the cells at $\frac{1}{4}$ and $\frac{1}{2} \times$ MIC of honeys (C: control; M: assay with branded honey; R: assay with unbranded honey.

\begin{tabular}{|c|c|c|c|c|c|c|c|c|c|c|c|c|c|c|c|c|c|c|}
\hline \multicolumn{19}{|c|}{ Minimum Inhibitory Concentration $(\% v / v ; \mu \mathrm{g} / \mathrm{mL})$} \\
\hline \multirow[t]{3}{*}{ Antimicrobial Agent } & \multicolumn{6}{|c|}{ E. coli ATCC 10536} & \multicolumn{6}{|c|}{ S. Typhi } & \multicolumn{6}{|c|}{ K. pneumoniae } \\
\hline & \multicolumn{3}{|c|}{ 4th P at $\frac{1}{4} \times$ MIC } & \multicolumn{3}{|c|}{ 4th $P$ at $\frac{1}{2} \times$ MIC } & \multicolumn{3}{|c|}{ 4th P at $\frac{1}{4} \times$ MIC } & \multicolumn{3}{|c|}{ 4th $P$ at $\frac{1}{2} \times$ MIC } & \multicolumn{3}{|c|}{ 4th P at $\frac{1}{4} \times$ MIC } & \multicolumn{3}{|c|}{ 4th $P$ at $\frac{1}{2} \times$ MIC } \\
\hline & $\mathrm{C}$ & $\mathbf{M}$ & $\mathbf{R}$ & $\mathrm{C}$ & $\mathbf{M}$ & $\mathbf{R}$ & $\mathrm{C}$ & $\mathbf{M}$ & $\mathbf{R}$ & $\mathrm{C}$ & $\mathbf{M}$ & $\mathbf{R}$ & $\mathrm{C}$ & $\mathbf{M}$ & $\mathbf{R}$ & $\mathrm{C}$ & $\mathbf{M}$ & $\mathbf{R}$ \\
\hline Branded honey $(\% v / v)$ & 25 & 25 & 25 & 25 & 25 & 25 & 12.5 & 12.5 & 12.5 & 12.5 & 12.5 & 12.5 & 25 & 25 & 25 & 25 & 25 & 25 \\
\hline Unbranded honey $(\% v / v)$ & 25 & 25 & 25 & 25 & 25 & 25 & 25 & 25 & 25 & 25 & 25 & 25 & 25 & 25 & 25 & 25 & 25 & 25 \\
\hline Gentamicin $(\mu \mathrm{g} / \mathrm{mL})$ & 2 & 2 & 2 & 2 & 2 & 2 & 2 & 2 & 2 & 2 & 2 & 2 & 2 & 2 & 2 & 2 & 2 & 2 \\
\hline Kanamycin $(\mu \mathrm{g} / \mathrm{mL})$ & 8 & 8 & 8 & 8 & 8 & 8 & 8 & 8 & 8 & 8 & 8 & 8 & 8 & 8 & 8 & 8 & 8 & 8 \\
\hline
\end{tabular}




\subsection{Influence of Honey Adaptation on the Development of Tolerance to Acid and Heat}

Food products are usually treated with high temperature and low $\mathrm{pH}$ at the industrial scale to eliminate harmful bacteria. In order to investigate the influence of honey adaptation by bacterial cells on tolerance to acid and heat, both adapted and unadapted bacterial cells were subjected to acid ( $\mathrm{pH} 2.5)$ and heat $\left(60^{\circ} \mathrm{C}\right)$ challenge assays.

The effect of the acidic environment ( $\mathrm{pH}$ 2.5) on survival rates of E. coli ATCC 10536, S. Typhi and K. pneumoniae after the fourth $\left(\frac{1}{4} \times \mathrm{MIC}\right)$ and eighth $\left(\frac{1}{2} \times \mathrm{MIC}\right)$ passage with branded and unbranded honey is shown in Figure 2. Percent survival of both adapted and unadapted cells of E. coli ATCC 10536 decreased during $120 \mathrm{~min}$ of incubation at low $\mathrm{pH}$ (2.5). However, percent survival of honey adapted $\left(\frac{1}{4} \times\right.$ MIC) cells of E. coli ATCC 10536 was significantly higher $\left({ }^{*} p<0.05\right)$ as compared to unadapted cells after 30, 60, 90 and 120 min of incubation (Figure 2A).

No significant difference $(p>0.05)$ was observed for honey adapted $\left(\frac{1}{2} \times\right.$ MIC) E. coli ATCC 10536 during 0, 30, 60 and $90 \mathrm{~min}$ except after $120 \mathrm{~min}$ (Figure 3D). Percent survival of honey adapted $\left(\frac{1}{4} \times\right.$ MIC) cells of $S$. Typhi and K. pneumoniae was found to be significantly higher $\left({ }^{*} p<0.05\right)$ as compared to unadapted cells after $120 \mathrm{~min}$ of incubation (Figure 2B,C,F). No significant increase in percent survival of honey adapted $\left(\frac{1}{2} \times\right.$ MIC) K. pneumoniae was noted during $120 \mathrm{~min}$ of incubation. A comparable pattern was previously reported with resveratrol, carvacrol and oregano essential oil adapted cells of S. aureus, L. monocytogenes under low $\mathrm{pH}(2.4)$ conditions $[23,26]$.

The effect of heat stress $\left(60^{\circ} \mathrm{C}\right)$ on survival rates of E. coli ATCC 10536, S. Typhi and K. pneumoniae after fourth $\left(\frac{1}{4} \times \mathrm{MIC}\right)$ and eighth $\frac{1}{2} \times \mathrm{MIC}$ ) passage with branded and unbranded honey is represented in Figure 3. A significant increase in percent survival was only seen in branded and unbranded honey adapted cells of E. coli ATCC 10536 and K. pneumoniae after $120 \mathrm{~min}$ of incubation at $60{ }^{\circ} \mathrm{C}$ (Figure 3A,C,F).

No significant difference in the percent survival of honey adapted cells was observed as compared to unadapted cells during 0, 30, 60 and 90 min of survival assays. Furthermore, a reduction in cell viability was found during $120 \mathrm{~min}$ of incubation at $60^{\circ} \mathrm{C}$. This reduction in cell viability could be related to proteins involved in cellular functions being inactivated to heat shock as reported previously [27]. Heat tolerance was previously observed in resveratrol adapted L. monocytogenes and S. aureus cells during incubation at $55^{\circ} \mathrm{C}[23]$.
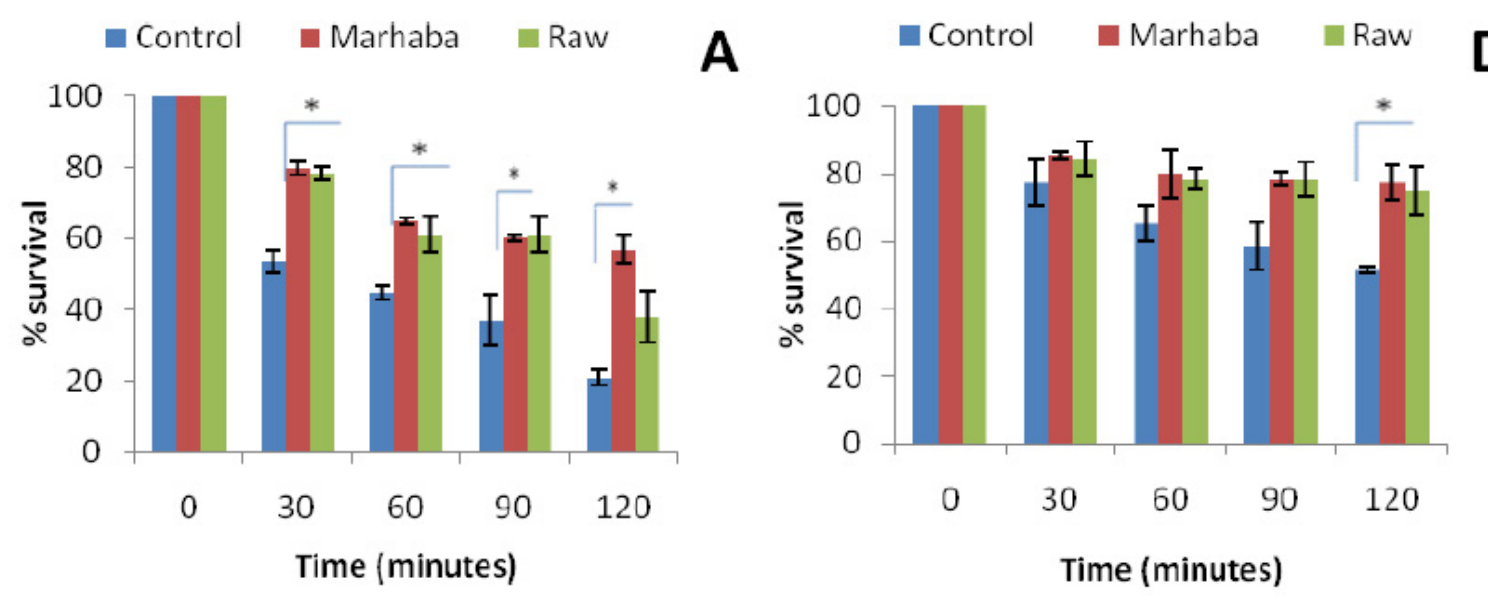

Figure 2. Cont. 

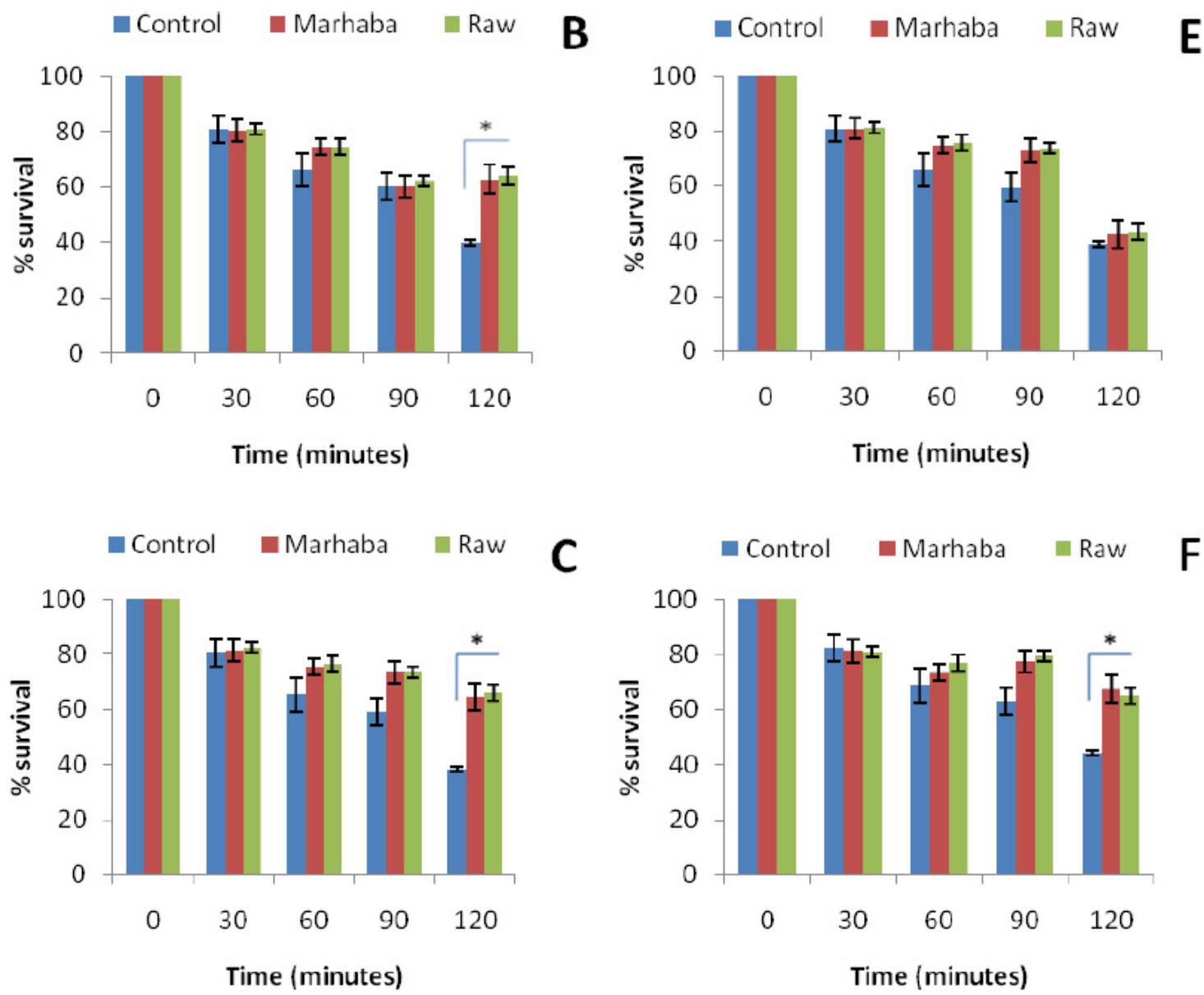

Figure 2. Effect of $\mathrm{pH}(2.5)$ in E. coli ATCC 10536 (A,D); S. Typhi (B,E) and K. pneumoniae (C,F) survival after the fourth passage of adaptation at $\frac{1}{4} \times \operatorname{MIC}(\mathbf{A}-\mathbf{C})$ and the eighth until $\frac{1}{2} \times$ MIC $(\mathbf{D}-\mathbf{F})$ of branded and unbranded honey. $(p>0.05) ;^{*}(p<0.05)$.
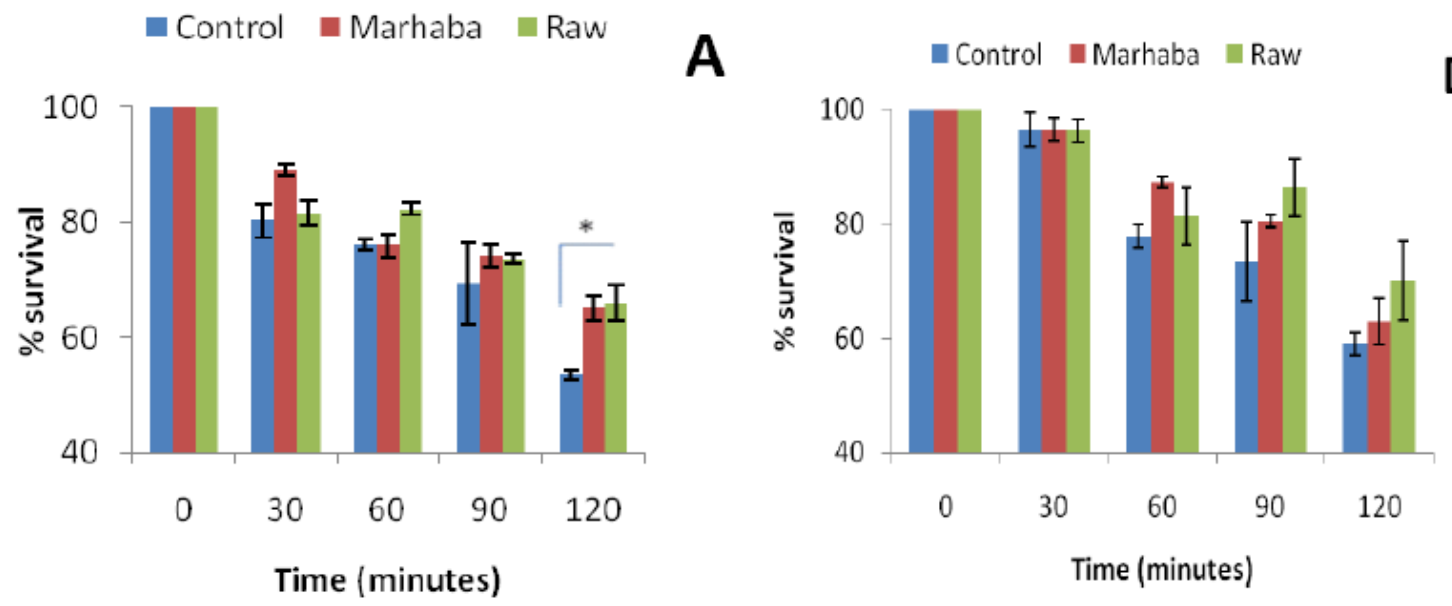

Figure 3. Cont. 

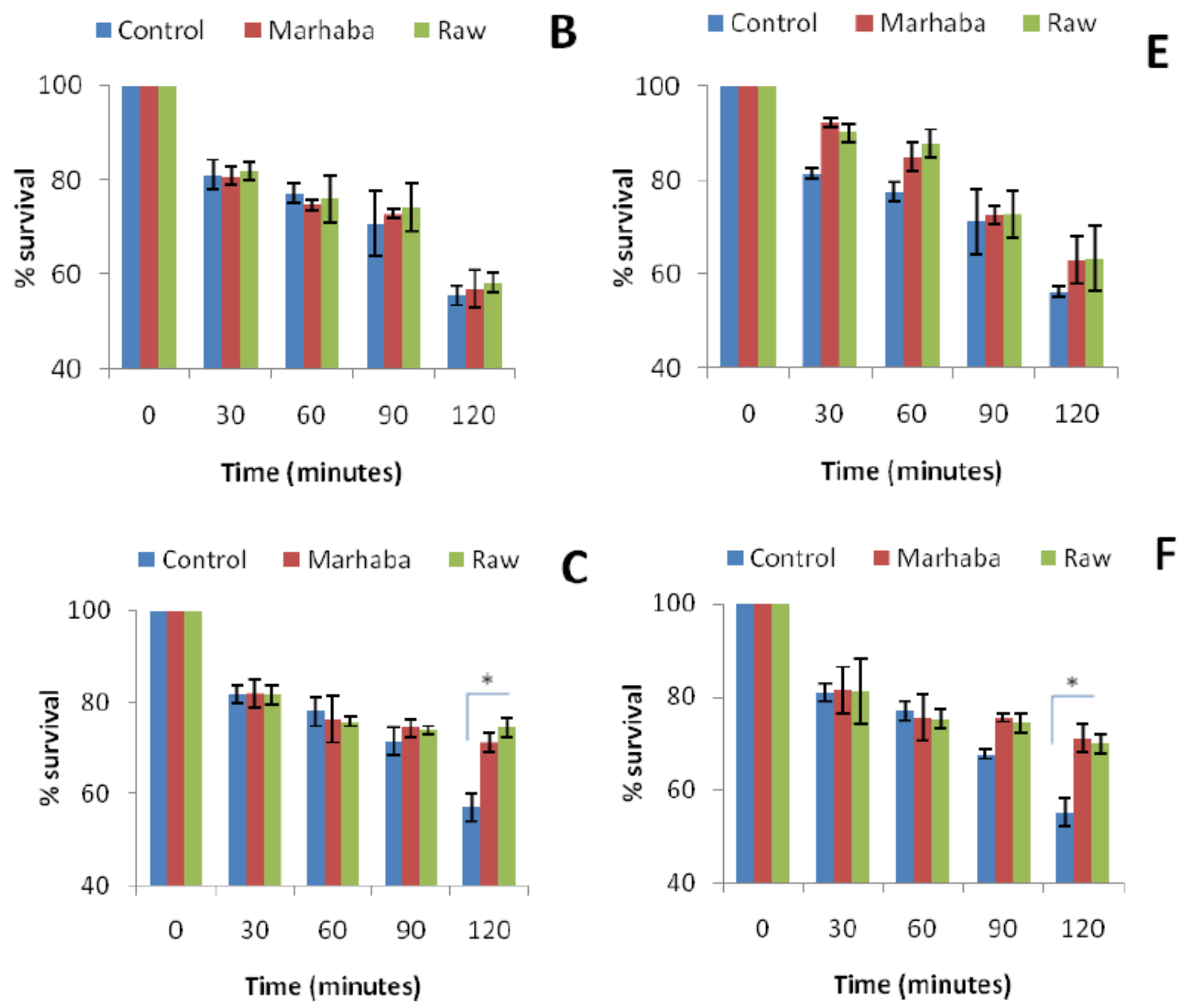

Figure 3. Effect of temperature $\left(60^{\circ} \mathrm{C}\right)$ in E. coli ATCC 10536 (A,D); S. Typhi (B,E) and K. pneumoniae $(\mathbf{C}, \mathbf{F})$ survival after the fourth passage of adaptation at $\frac{1}{4} \times$ MIC $\left(\right.$ A-C) and the eighth until $\frac{1}{2} \times$ MIC (D-F) of branded and unbranded honey. $(p>0.05) ; *(p<0.05)$.

\section{Conclusions}

The development of novel antimicrobial strategies in foods is of prior importance to the food industry to ensure safe food to consumers. However, it is also important to understand the capability of microorganisms to develop resistance against sub-lethal and lethal inhibitory concentrations of antimicrobial compounds. Our results revealed that both branded honey (Marhaba) and unbranded honey (extracted from Ziziphus mauritiana plant) were effective in controlling the growth of tested pathogenic bacteria. No emergence of self or cross-resistance was observed in adapted cells. However, the emergence of tolerance to high temperature $\left(60^{\circ} \mathrm{C}\right)$ and low $\mathrm{pH}(2.5)$ in adapted cells deserves further investigation, before proposing honey as a better antibacterial agent in food fabrication/processing, where low $\mathrm{pH}$ and high temperatures are usually implemented.

Author Contributions: Conceptualization, M.I.A.; data curation, K.I., M.I., A.U. and M.I.A.; formal analysis, R.A., M.U. and B.R.; investigation, T.Y., S.A (Shabbar Abbas). and M.S., S.A. (Sohail Afzal), F.A. and N.C.; methodology, A.A.M.; supervision, M.I.A.; visualization, M.K.I.K., M.S.A. and Z.H.S.; writing—original draft, R.A.; writing-review \& editing, M.I.A. All authors have read and agreed to the published version of the manuscript.

Funding: This research received no external funding.

Conflicts of Interest: The authors declare no conflict of interest. 


\section{References}

1. Muhammad, A.; Odunola, O.A.; Ibrahim, M.A.; Sallau, A.B.; Erukainure, O.L.; Aimola, I.A.; Malami, I. Potential biological activity of acacia honey. Front. Biosci. 2016, 8, 351-357. [CrossRef]

2. Khan, S.U.; Anjum, S.I.; Rahman, K.; Ansari, M.J.; Khan, W.U.; Kamal, S.; Khattak, B.; Muhammad, A.; Khan, H.U. Honey: Single food stuff comprises many drugs. Saudi J. Biol. Sci. 2018, 25, 320-325. [CrossRef]

3. Denisow, B.; Denisow-Pietrzyk, M. Biological and therapeutic properties of bee pollen: A review. Asian J. Agric. Food Sci. 2016, 96, 4303-4309. [CrossRef]

4. Olaitan, P.B.; Adeleke, O.E.; Iyabo, O. Honey: A reservoir for microorganisms and an inhibitory agent for microbes. Afr. Health Sci. 2007, 7, 159-165. [PubMed]

5. Buba, F.; Gidado, A.; Shugaba, A. Analysis of biochemical composition of honey samples from North-East Nigeria. Anal. Biochem. 2013, 2,1-7.

6. Khalil, M.; Sulaiman, S.; Boukraa, L. Antioxidant properties of honey and its role in preventing health disorder. Open Nutraceuticals J. 2010, 3, 6-16. [CrossRef]

7. Bogdanov, S.; Jurendic, T.; Sieber, R.; Gallmann, P. Honey for nutrition and health: A review. J. Am. Coll. Nutr. 2008, 27, 677-689. [CrossRef] [PubMed]

8. Liyanage, D.; Mawatha, B. Health benefits and traditional uses of honey: A review. J. Apith. 2017. [CrossRef]

9. Ball, D.W. The chemical composition of honey. J. Chem. Educ. 2007, 84, 1643. [CrossRef]

10. Mandal, S.; DebMandal, M.; Pal, N.K.; Saha, K. Antibacterial activity of honey against clinical isolates of Escherichia coli, Pseudomonas aeruginosa and Salmonella enterica serovar Typhi. Asian Pac. J. Trop. Dis. 2010, 3, 961-964. [CrossRef]

11. Mandal, M.D.; Mandal, S. Honey: Its medicinal property and antibacterial activity. Asian Pac. J. Trop. Biomed. 2011, 1, 154. [CrossRef]

12. Irish, J.; Blair, S.; Carter, D.A. The antibacterial activity of honey derived from Australian flora. PLoS ONE 2011, 6, e18229. [CrossRef] [PubMed]

13. Voidarou, C.; Alexopoulos, A.; Plessas, S.; Karapanou, A.; Mantzourani, I.; Stavropoulou, E.; Fotou, K.; Tzora, A.; Skoufos, I.; Bezirtzoglou, E. Antibacterial activity of different honeys against pathogenic bacteria. Anaerobe 2011, 17, 375-379. [CrossRef] [PubMed]

14. Abd-El Aal, A.M.; El-Hadidy, M.R.; El-Mashad, N.B.; El-Sebaie, A.H. Antimicrobial effect of bee honey in comparison to antibiotics on organisms isolated from infected burns. Ann. Burns Fire Disasters 2007, 20, 83-88. [PubMed]

15. Majtan, J.; Bohova, J.; Horniackova, M.; Klaudiny, J.; Majtan, V. Anti-biofilm Effects of Honey Against Wound Pathogens Proteus mirabilis and Enterobacter cloacae. Phytother Res. 2014, 28, 69-75. [CrossRef] [PubMed]

16. Rahman, K.; Hussain, A.; Ullah, S.; Muhammad Zai, I.U. Phytochemical analysis and chemical composition of different branded and unbranded honey samples. Int. J. Microbiol Res. 2013, 4, 132-137.

17. Clinical and Laboratory Standards Institute (CLSI). Performace Standards for Antimicrobial Susceptibility Testing; Twenty-Second Informational Supplement M100eS22; Clinical and Laboratory Standards Institute (CLSI): Wayne, PA, USA, 2012; Volume 32, pp. 1-188.

18. Almasaudi, S.B.; Al-Nahari, A.A.; El Sayed, M.; Barbour, E.; Al Muhayawi, S.M.; Al-Jaouni, S.; Azhar, E.; Qari, M.; Qari, Y.A.; Harakeh, S. Antimicrobial effect of different types of honey on Staphylococcus aureus. Saudi J. Biol. Sci. 2017, 24, 1255-1261. [CrossRef]

19. Apolónio, J.; Faleiro, M.L.; Miguel, M.G.; Neto, L. No induction of antimicrobial resistance in Staphylococcus aureus and Listeria monocytogenes during continuous exposure to eugenol and citral. FEMS Microbiol. Lett. 2014, 354, 92-101. [CrossRef]

20. Szczepanska, B.; Andrzejewska, M.; Spica, D.; Klawe, J.J. Prevalence and antimicrobial resistance of Campylobacter jejuni and Campylobacter coli isolated from children and environmental sources in urban and suburban areas. BMC Microbiol. 2017, 17. [CrossRef]

21. Lundén, J.; Tolvanen, R.; Korkeala, H. Acid and heat tolerance of persistent and nonpersistent Listeria monocytogenes food plant strains. Lett. Appl. Microbiol. 2008, 46, 276-280. [CrossRef]

22. Steel, R.; Torrie, J.; Dickie, M. Principles and Procedures of Statistics; McGraw Hill: New York, NY, USA, 1997.

23. Oliveira, A.R.; Domingues, F.C.; Ferreira, S. The influence of resveratrol adaptation on resistance to antibiotics, benzalkonium chloride, heat and acid stresses of Staphylococcus aureus and Listeria monocytogenes. Food Control. 2017, 73, 1420-1425. [CrossRef] 
24. Allen, K.J.; Wałecka-Zacharska, E.; Chen, J.C.; Katarzyna, K.-P.; Devlieghere, F.; Van Meervenne, E.; Osek, J.; Wieczorek, K.; Bania, J. Listeria monocytogenes-An examination of food chain factors potentially contributing to antimicrobial resistance. Food Microbiol. 2016, 54, 178-189. [CrossRef]

25. Cooper, R.; Jenkins, L.; Henriques, A.; Duggan, R.; Burton, N. Absence of bacterial resistance to medical-grade manuka honey. Eur. J. Clin. Microbiol. Infect. Dis. 2010, 29, 1237-1241. [CrossRef] [PubMed]

26. Silva Da Luz, I.; Gomes Neto, N.J.; Tavares, A.G.; Nunes, P.C.; Magnani, M.; De Souza, E.L. Lack of induction of direct protection or cross-protection in Staphylococcus aureus by sublethal concentrations of Origanum vulgare L. essential oil and carvacrol in a meat-based medium. Arch. Microbiol. 2013, 195, 587-593. [CrossRef] [PubMed]

27. Bikels-Goshen, T.; Landau, E.; Saguy, S.; Shapira, R. Staphylococcal strains adapted to epigallocathechin gallate (EGCG) show reduced susceptibility to vancomycin, oxacillin and ampicillin, increased heat tolerance, and altered cell morphology. Int. J. Food Microbiol. 2010, 138, 26-31. [CrossRef] [PubMed]

(C) 2020 by the authors. Licensee MDPI, Basel, Switzerland. This article is an open access article distributed under the terms and conditions of the Creative Commons Attribution (CC BY) license (http://creativecommons.org/licenses/by/4.0/). 